DOI:

UDC 004.9

L. Korotka, Candidate of Technical Sciences (Ph. D.), Docent, korliv@hotmail.com Ukrainian State University of Chemical Technology Department of Information Systems, Dnipro

\title{
THE USE OF FUZZY CLUSTERING IN SOLVING PROBLEM IN PREDICTING THE DURABILITY OF CORROSIVE STRUCTURES
}

In solving the problems of forecasting corroding structures, the problematic aspects related to computational costs are considered. It is proposed to use a multi-stage approach to reduce computational costs in solving tasks of this class. In particular: a fuzzy clustering algorithm is used for processing multivariate data; the resulting clusters are used to build the rule base; and the fuzzy logical output of the Mamdani type is used for defasification.

Keywords: fuzzy clustering; fuzzy knowledge base; fuzzy inference; corrosive structures.

При розв'язанні задач прогнозування кородуючих конструкцій розглянуто проблемні аспекти, які пов'язані з обчислювальними витратами. Запропоновано багатоетапний підхід задля зменшення обчислювальних витрат при розв'язання задач такого класу. А саме:для обробки багатовимірних даних використовується алгоритм нечіткої кластеризаиії; для побудови опорної бази правил застосовуються отримані кластери; для дефазифікаиіі виконується нечітке логічне виведення типу Мамдані.

Ключові слова: нечітка кластеризація; нечітка база знань; нечітке виведення; кородуючі конструкиї.

\section{Problem's Formulation}

A lot of work has been devoted to the study of methods for processing multidimensional data arrays in various subject areas, and these studies are far from complete [3, 17, 18, 21]. Before starting work with such data, it is necessary to carry out preliminary processing, if possible, for example, remove abnormal or noisy elements, etc.

One of the directions of processing multidimensional arrays of various structures is cluster data analysis, which allows you to sort heterogeneous data into subsets of a more or less homogeneous structure $[2,14]$.

There are a sufficient number of clustering methods with various metrics that can be grouped as clear and fuzzy. Using clear clustering methods allows you to split the original set of objects into several, as a rule, disjoint subsets [2,14-16]. It is assumed that any object from the obtained partition into subsets belongs to the only cluster. Fuzzy clustering methods allow to split the source data into subsets in such a way that an element can belong to several clusters with different degrees of membership at the same time. Obviously, the use of clear or fuzzy clustering methods is entirely dependent on the problem being solved. The advantages and disadvantages of clustering methods are known.

The subject area of work is predicting the durability of a structure with changing geometric characteristics, which functions in an aggressive external environment (direct task) (fig. 1) [11, 20, 21 ].

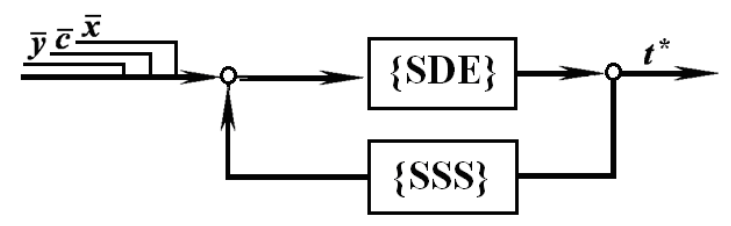

Fig. 1. Structural scheme of the solution for the problem of predicting durability 
Here $\bar{x}$ - vector of geometric characteristics; $\bar{c}$ — aggressive parameter vector (AE); $\bar{y}-$ vector of constant parameters; $t^{*}$ - estimated durability. Here the modules $\{\mathrm{SSS}\}$ and $\{\mathrm{SDE}\}$ are respectively the modules for calculating the stress-strain state (SSS) and solving the system of differential equations (SDE), which describes the corrosion wear.

The destabilizing factor of the external environment is corrosion, and the generalized parameter is its speed. Joint corrosion interaction with mechanical loads often leads to premature, and sometimes to emergency, structural failure. Therefore, we have a dynamic mechanical system that operates in an aggressive environment, the behavior of which and the timing of its operation must be predicted.

The problem of solving the problem of predicting the durability of corroding structures (CS) is of independent importance, it should be emphasized that it is an integral part of the optimization problem (inverse problem) (fig. 2): the stage of calculating the constraint functions (CF) [21].

When solving optimization problems, the problem of increasing the efficiency of computational methods and costs is especially relevant. $\mathrm{n}$ view of the fact that the task of predicting the CS durability has been repeatedly solved, there is rather scattered information in the form of multidimensional data arrays that require some formalization.

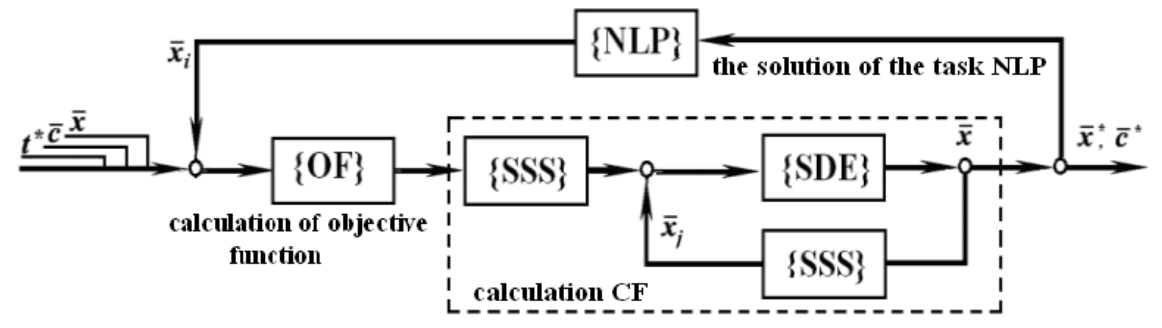

Fig. 2. Structural scheme of the solution for the optimization task

Here modules $\{\mathrm{SSS}\}$ and $\{\mathrm{SDE}\}$ have the same meaning as before, $\{\mathrm{OF}\}-$ block for calculating the objective function; $\{$ NLP $\}$ - module for solving the problem of nonlinear mathematical programming

Analysis of recent research and publications

When solving the CDE in many works the integration step was a parameter of the problem to be solved, which was chosen by an expert in the subject field quite intuitively. Obviously, this approach does not allow to obtain a solution to the task with a certain accuracy: it can be either overpriced or underestimated, which negatively affects the computational cost.

The considered error will depend on the following factors: initial geometric characteristics of the element (area $A_{0}$ and perimeter $P_{0}$ ), initial $\sigma_{0}$ and ultimate $[\sigma]$ voltages in it, parameters of the corrosion process and the maximum permissible error value $[\varepsilon]$. Therefore, the error of the numerical solution of the differential equation describing the corrosion wear (4) can be represented as a function of several variables: $\varepsilon\left(v_{0}, A_{0}, P_{0}, \sigma_{0},[\sigma], h_{t}\right)[11,20,21]$.

As a control module, neural network algorithms are offered that have proven themselves quite well. However, the use of neural networks has its advantages and disadvantages [9, 20]. Neural networks (NN), as you know, are universal approximating systems and are based on a specific mathematical apparatus.

There are a lot of works devoted to problems of approximation using neural networks in various subject areas [21]. The NN are the undisputed leaders in this direction. However, the success of using a neural network usually requires a significant number of experiments; an important factor is the volume and quality of training data; in addition, a certain network architecture must have and the parameters of its training. The process of training, testing and tuning the network itself requires some time and effort from its designer [21]. 
In addition to neural networks, combined approaches using genetic algorithms and $\mathrm{NN}$ are proposed for solving such tasks $[8,10,20]$. As a rule, the use of one or another approach is determined by the class of tasks being solved and computational costs that are spent on obtaining a solution [21].

\section{Formulation of the study purpose}

The purpose of the work is to create some control module, which allows to formalize the existing information and obtain parameters of numerical procedures, which allow to obtain a solution with an error not higher than the specified. The general statement of the problem includes the following successive steps:

1) using the fuzzy clustering algorithm for processing multidimensional data arrays in order to formalize this information and build a fuzzy model for the prediction of the durability of a corroding structure;

2) obtaining a basic rule base based on fuzzy clustering (fcm algorithm) to build a fuzzy knowledge base;

3) the use of fuzzy inference techniques (for example, Mamdani type) and defuzzification of results (for example, using the heights method).

\section{Presenting main material}

Mathematical statement of the problem of predicting the CS durability with accuracy control during modeling.

The mathematical model of structural deformation in the $\mathrm{AE}$ will include:

a system of differential equations describing a corrosion process of the form (module SDE):

$$
\frac{d \delta_{i}}{d t}=v_{0} \cdot \psi\left\{\sigma_{i}(\bar{\delta})\right\}, i=\overline{1, N}
$$

With initial conditions:

$$
\left.\bar{\delta}\right|_{t=0}=0 .
$$

Here $N$ - the number of parameters that determine the geometric dimensions of the structure; $\delta_{i}$ — depth of corrosion damage (damage parameter); $t$ - time; $v_{0}$ - stress free corrosion rate; $\sigma_{i}$ — voltage in the $i$-th element of time $t ; \psi\left\{\sigma_{i}(\bar{\delta})\right\}$ — some famous function;

2) system of equations of the finite element method (module SSS);

3) limit state equations: conditions of strength and stability. The design retains the bearing capacity as long as the following system of restrictions is implemented:

$$
\begin{gathered}
{[\sigma]-\sigma_{i}(t, \bar{c}) \geq 0 ; \quad i=\overline{1, N}} \\
\sigma_{j}^{*}(t)-\sigma_{j}(t, \bar{c}) \geq 0 ; \quad j \in J
\end{gathered}
$$

where $[\sigma]$ - allowable voltage; $\sigma_{i}(t)$ - current voltage in the $i$-th element; $\sigma_{j}$ - critical voltage loss of stability; $J$ - many elements working on compression; $N$ - number of elements in the system. The first system of inequalities determines the condition for the strength of structural elements, the second - the condition of stability.

Then the problem statement of the algorithm for controlling the accuracy of the numerical result for a given error in solving the tasks of forecasting the CS durability can be formulated as follows [4]:

$$
\left\{\begin{array}{l}
h_{t}(\varepsilon, \bar{c}) \rightarrow \max \\
\varepsilon\left(\bar{c}, h_{t}\right) \leq[\varepsilon]
\end{array}\right.
$$

Here $\bar{c}=\left\{\sigma_{0}, v_{0}, A_{0}, P_{0}\right\}$ - vector of factors affecting the size of the integration step, which includes the parameters of an aggressive environment; $\sigma_{0}-$ initial stresses; $A_{0}, P_{0}-$ respectively, the area and perimeter of the section of the CS element; $\varepsilon,[\varepsilon]$ - respectively, the obtained and maximum permissible error value of the numerical solution; $h_{t}-$ the parameter of numerical procedures. 
For definiteness, the mathematical model of V. Dolinsky $[11,13,21]$ was used in the work as a model of corrosion wear:

$$
\frac{d \delta}{d t}=v_{0} \cdot\left[1+k \cdot \sigma_{e q}\right],
$$

where $k$-coefficient of influence of stresses on corrosion rate.

The procedure for determining the voltage in the right-hand sides of the SDE (4) is a computational algorithm, the system can only be solved numerically, and the voltage calculation is carried out at each node of the time grid.

When solving the system of differential equations (4), in fact, the main computational costs are associated with a rational choice of parameters of numerical procedures. As for one subset of multidimensional data, $\left\{\sigma_{0}, v_{0}, A_{0}, P_{0}, h_{t},[\varepsilon]\right\}$ the size of the integration step $h_{t}$ can lead to excessive computational costs, and for another subset of it, to be insufficient.

According to the author, when solving SDE (4) to control the accuracy of the result, neurofuzzy technologies can be used. It is proposed to control the error of the numerical solution using a multi-stage approach, which includes an algorithm that takes into account information about the factors affecting the error of the numerical solution of the SDE (4). The algorithm allows to choose the appropriate parameters of numerical procedures and providing the required accuracy of calculations.

Neuro-fuzzy approaches are an alternative to NN, according to the FAT theorem [7], an approximating system of computational intelligence based on fuzzy logical inference of the Mamdani type is proposed $[1,15]$.

As noted earlier, the task of predicting durability has been repeatedly solved and information about the relationship between the given accuracy, the parameters of numerical integration and the values that affect them are not systematized. It is proposed to formalize this knowledge in the form of a model of a system of fuzzy logical inference, which for each particular case will find the value of the parameter of numerical procedures and provide a given accuracy of calculations.

In $[4,21]$, the possibility of obtaining training samples is substantiated not for the structure as a whole, but for its individual elements. This allows, on the one hand, to simplify the solution of the task of predicting durability for a training sample, and on the other hand, to create a sufficiently universal model of fuzzy inference for calculating articulated-rod structures with arbitrary geometry, boundary conditions, and loading conditions.

It is proposed to formalize multidimensional data arrays using the fcm-algorithm of fuzzy clustering. Input data are: initial voltage $\sigma_{0}$; corrosion rate in the absence of voltage $v_{0}$; respectively, the area and perimeter of the section of the element of the corroding structure $A_{0}, P_{0}$; SDE numerical integration parameter - integration step $h_{t}$; real error of the numerical solution of the $\operatorname{SDE} \varepsilon$, which should not be higher than a given $[\varepsilon]$; the estimated value of the durability of CS $t^{*}$.

It is proposed to use clusters after breaking into subsets to build a fuzzy knowledge base (FKB). Let us describe this process in more detail and in stages.

The optimal number of clusters should be established for the best partitioning of the data array into subsets. There is currently no formalized approach to solving this problem. The choice of a certain number of clusters depends on the designer of the fuzzy logical inference system (FLIS) [12]. In the work, this was established empirically, taking into account the fact that each individual cluster will serve as a reference rule for the FKB. Almost after fuzzy clustering, we get a system of support rules for the knowledge base. In addition, these rules can be improved, for example, by adding or removing some of them, as well as by revising the number of term sets for fuzzy model variables. In this case, the designer of the FLIS may ascribe the significance factors of the rules $(0 ; 1]$. It should be noted that for the supporting rules this coefficient is equal to one.

Obviously, the main elements of the knowledge base are products that include terms of linguistic variables $(\mathrm{LV})\left\{\sigma_{0}, v_{0}, A_{0}, P_{0},[\varepsilon], h_{t}, t^{*}\right\}$ [19]. After clustering and analysis of support rules, using the numerical values of the variables that are used to determine the terms of each linguistic variable, taking into account the obtained values of their membership functions. As noted in some sources, a rational number of terms is considered to be from two to nine. The basic terms used are the 
values of the LV: low (L), below average (BA), medium (M), above average (AA), below high (BH), high $(\mathrm{H})$, which can be supplemented or combined into other values after analysis of the results of clustering.

It is proposed to consider the boundaries of each cluster as a carrier of a fuzzy set, which then expand through the use of fuzzy clustering. This is possible due to the fact that when using fuzzy clustering, the degree of belonging of the boundaries of the clusters is not less than $0,45-0,5$. Therefore, the carrier of the fuzzy set itself is much wider than the obtained cluster boundaries. In fact, the designer of the FKB determines the domain of definition of the membership function. According to the author, this process does not require additional explanation.

The next step in the construction of the FKB is the definition and setting of semantic and syntactic rules for the definition of each linguistic variable.

The center of each cluster is proposed to be regarded as the core of a fuzzy set with a membership degree of unity. To construct membership functions, the $\alpha$-level principle of L. Zadeh generalization was used [12]. The process of determining the term sets of linguistic variables can be considered complete.

The next stage of the work is the analysis of the built FKB. As noted in [12], as the number of rules or terms of fuzzy sets increases (increasing the level of complexity of the model), the ability of a fuzzy model to describe a real system proportionally improves. With this approach, it is possible to obtain an isomorphic model of the system, which eliminates the entire modeling process (including fuzzy ones). In addition, with this approach, an exponential growth (the so-called "curse of dimension") of the number of rules of the number of model inputs and the number of fuzzy sets in it occurs.

The proposed approach allows to state that the constructed fuzzy model and fuzzy partition of the range of values of all variables are complete [12], since each input state associates a fuzzy model with some output value.

The fuzzy rule base is numerically complete, since each input state leads to the activation of at least one rule. The basic rule base is complete and consistent, that is, it does not contain conflicting rules.

Fuzzy clustering allows to get the term sets of each linguistic variable The support base of the model rules is linguistically complete, since each input linguistic state is associated with at least one output linguistic state. All these properties will be demonstrated as a result of numerical experiments.

Thus, the stage of formalizing information on each cluster in the form of a model for representing a fuzzy knowledge base can be considered as completed.

After building and setting up a fuzzy knowledge base, it is possible proceed to work directly with it. In this case, when setting the input values $\left\{\sigma_{0}, v_{0}, A_{0}, P_{0},[\varepsilon]\right\}$ the output will be interested in the values of the integration step $h_{t}$, which the predicted value of the durability $t^{*} \mathrm{CS}$ will be obtained for the maximum permissible error $[\varepsilon]$ of the numerical solution of the SDE (4).

The process of building the FKB can be considered completed. We have a predetermined rule base in which all input and output linguistic variables are defined. Further, the well-known methods of fuzzy inference can be used (in the work the Mamdani algorithm). And the final stage of the proposed phased approach is to obtain not only the interval value of the predicted durability, but its exact value. Without loss of generality of reasoning, the method of heights was used, which is a simplified discrete version of the method of centers.

The obtained defuzzified value fully satisfies the set requirements, since with well-defined input data: (initial voltage $\sigma_{0}$, corrosion rate $v_{0}$ and geometric characteristics of system elements $P_{0}$, $A_{0}$ ) with the given parameters of numerical procedures $h_{t}$ and the required accuracy $[\varepsilon]$; a knowledge-based system will provide a predicted value of durability with a certain degree of expert confidence.

This approach allows to reduce computational costs when solving both direct and inverse problems. When solving the optimization problem, the calculation of the constraint functions entails the main computational costs. 


\section{Numerical experiments}

As noted earlier, the task of predicting the durability of corroding structures was solved many times (the amount of training data from thousands of samples), therefore there are multidimensional arrays of disordered information. To solve the direct task, it is necessary to approximate $t *=F\left(\sigma_{0}, v_{0}, A_{0}, P_{0}, h_{t},[\varepsilon]\right)$, where $F$ - unknown function, which is a function of constraints in solving the inverse task. For definiteness, a five-element hinged-rod structure was considered as a model design. The proposed approach in this work does not in any way narrow the class of tasks under consideration.

According to this approach, for the formation of terms of linguistic variables based on clusters, in general terms, the rule of a fuzzy knowledge base can be represented:

$$
R^{(k)}: \quad \operatorname{IF}\left([\sigma]=T_{i}^{j} \wedge v_{0}=T_{i}^{j} \wedge\left(A_{0} / P_{0}\right)=T_{i}^{j} \wedge[\varepsilon]=T_{i}^{j} \wedge h_{t}=T_{i}^{j}\right), \quad \quad \text { THEN } t *=T_{i}^{j}
$$

Here $T_{i}^{j}$ - corresponding term sets of linguistic variables; $i$ - term number of each variable $(i=\overline{2, N}), N$ - maximum number of terms $\left(N \leq N_{k l}\right) ; j$ - number of the variable itself $(j=\overline{1,6})$; $R^{(k)}$ — the corresponding $k$-th rule of $\mathrm{FKB}\left(k \leq N_{k l}\right)$.

\begin{tabular}{|c|c|c|c|c|c|}
\hline Clusters & $\begin{array}{l}\text { The boundaries } \\
\text { of the first } \\
\text { cluster, } \\
\text { (Centre) }\end{array}$ & $\begin{array}{l}\text { The boundaries } \\
\text { of the second } \\
\text { cluster, } \\
\text { (Centre) }\end{array}$ & $\begin{array}{l}\text { The boundaries } \\
\text { of the third } \\
\text { cluster, } \\
\text { (Centre) }\end{array}$ & $\begin{array}{l}\text { The boundaries } \\
\text { of the fourth } \\
\text { cluster, } \\
\text { (Centre) }\end{array}$ & $\begin{array}{l}\text { The boundaries } \\
\text { of the fifth } \\
\text { cluster, } \\
\text { (Centre) }\end{array}$ \\
\hline $\begin{array}{l}\text { Initial } \\
\text { voltage } \sigma_{0}, \\
M P a\end{array}$ & $\begin{array}{c}{[907,977 ; 999,498]} \\
(945,062)\end{array}$ & $\begin{array}{c}{[580,737 ; 644,630]} \\
(616,643)\end{array}$ & $\begin{array}{c}{[362,295 ; 466,158]} \\
(407,335)\end{array}$ & $\begin{array}{c}{[826,862 ; 907,580]} \\
(870,678)\end{array}$ & $\begin{array}{c}{[525,846 ; 577,952]} \\
(544,560)\end{array}$ \\
\hline $\begin{array}{l}\text { Corrosion } \\
\text { rate } v_{0}, \\
\mathrm{~cm} / \text { year }\end{array}$ & $\begin{array}{c}{[0,0800 ; 0,1179]} \\
(0,1117)\end{array}$ & $\begin{array}{c}{[0,1034 ; 0,1075]} \\
(0,1052)\end{array}$ & $\begin{array}{c}{[0,0800 ; 0,1199} \\
(0,1104)\end{array}$ & $\begin{array}{c}{[0,0805 ; 0,1199]} \\
(0,1012)\end{array}$ & $\begin{array}{c}{[0,1075 ; 0,1106]} \\
(0,1095)\end{array}$ \\
\hline $\begin{array}{l}\text { Areas } A_{0}, \\
\mathrm{~cm}^{2}\end{array}$ & $\begin{array}{c}{[27,5232 ; 31,4642]} \\
(28,6164)\end{array}$ & $\begin{array}{c}{[6,3502 ; 7,7540]} \\
(6,9759) \\
\end{array}$ & $\begin{array}{c}{[11,3125 ; 13,4514]} \\
(12,4921)\end{array}$ & $\begin{array}{c}{[28,1413 ; 35,2489]} \\
(35,0596)\end{array}$ & $\begin{array}{c}{[7,9553 ; 8,9559]} \\
(8,6894) \\
\end{array}$ \\
\hline $\begin{array}{l}\text { Perimeter } \\
P_{0}, \mathrm{~cm}\end{array}$ & $\begin{array}{c}{[19,8775 ; 29,8640]} \\
(26,2053)\end{array}$ & $\begin{array}{c}{[14,4766 ; 15,3306]} \\
(14,8736)\end{array}$ & $\begin{array}{c}{[16,4189 ; 17,8921]} \\
(17,0901)\end{array}$ & $\begin{array}{c}{[20,0793 ; 30,5627]} \\
(26,1040)\end{array}$ & $\begin{array}{c}{[15,2622 ; 15,8366]} \\
(15,6333)\end{array}$ \\
\hline $\begin{array}{l}\text { The } \\
\text { maximum } \\
\text { permissible } \\
\text { error value, } \\
{[\varepsilon]}\end{array}$ & $\begin{array}{c}{[0,04800 ; 0,05200]} \\
(0,04930)\end{array}$ & $\begin{array}{c}{[0,04813 ; 0,05194]} \\
(0,04981)\end{array}$ & $\begin{array}{c}{[0,04801 ; 0,05199]} \\
(0,05000)\end{array}$ & $\begin{array}{c}{\left[\begin{array}{c}0,04800 ; 0,05200] \\
(0,05038)\end{array}\right.}\end{array}$ & $\begin{array}{c}{[0,04803 ; 0,05197]} \\
(0,05007)\end{array}$ \\
\hline $\begin{array}{l}\text { Parameter of } \\
\text { numerical } \\
\text { procedures, } \\
h_{t}, \text { years }\end{array}$ & $\begin{array}{c}{[1,1590 ; 1,9993]} \\
(1,4177)\end{array}$ & $\begin{array}{c}{[0,2529 ; 0,2817]} \\
(0,2675)\end{array}$ & $\begin{array}{c}{[0,2124 ; 0,3393]} \\
(0,2537)\end{array}$ & $\begin{array}{c}{[1,1248 ; 1,9921]} \\
(1,5830)\end{array}$ & $\begin{array}{c}{[0,2478 ; 0,2798]} \\
(0,2625)\end{array}$ \\
\hline $\begin{array}{l}\text { The } \\
\text { forecasted } \\
\text { value of } \\
\text { durability, } \\
t^{*} \text {, years }\end{array}$ & $\begin{array}{c}{[3,9378 ; 7,0418]} \\
(4,9972)\end{array}$ & $\begin{array}{c}{[2,5025 ; 2,9782]} \\
(2,7041)\end{array}$ & $\begin{array}{c}{[4,0852 ; 7,4706]} \\
(5,1497)\end{array}$ & $\begin{array}{c}{[4,9577 ; 7,4959]} \\
(6,6710)\end{array}$ & $\begin{array}{c}{[3,0165 ; 3,5024]} \\
(3,3200)\end{array}$ \\
\hline
\end{tabular}

The results of fuzzy clustering using fcm-algorithm are shown in tabl. 1.

Table 1. The results of fuzzy clustering for five clusters 
Using the data obtained after clustering, we can record a support base of five rules in the following form:

$$
\begin{array}{cc}
R^{(1)}: & H \& H \& H \& L \& L \& A A \rightarrow M \\
R^{(2)}: & M \& B A \& L \& L \& B A \& M \rightarrow L \\
R^{(3)}: & L \& A A \& M \& M \& M \& L \rightarrow A A \\
R^{(4)}: & A A \& L \& B H \& B H \& H \& H \rightarrow H \\
R^{(5)}: & B A \& M \& B A \& B A \& A A \& B A \rightarrow B A
\end{array}
$$

An analysis of the obtained rules allows to determine this rule base to numerically complete. There are several options and it all depends on the designer of the fuzzy knowledge base. We can start by analyzing the input variables. In particular, linguistic variables, the area $A_{0}$ and perimeter of structural elements, take the same values of term sets. Therefore, they can be considered as a single variable (for example, as the ratio $A_{0} / P_{0}$ ) and, thus, reduce the number of input variables of the fuzzy model under consideration. It should be noted that the following are the results for one input variable: the ratio of area and perimeter $A_{0} / P_{0}$.

As noted earlier, the structures operate in the $\mathrm{AE}$, therefore, if we assume that the area is "highly aggressive" [4-6, 21], then to simplify the fuzzy model, we can reduce the number of input variables and by assuming that the corrosion rate is constant, for example, $v_{0}=0,1 \mathrm{~cm} /$ year. For the same purpose, preliminary clustering can be carried out according to the maximum permissible error values $[\varepsilon]$.

Configuring the FKB can also be carried out by supplementing the support base of the rules. This process is the most time-consuming and is implemented through the analysis of working / active rules, where there is an "imposition" of neighboring term-sets of linguistic variables and the degree of belonging of the elements is close to 0,5 . For example, rule two and five can be supplemented by at least one of the rules for linguistic variables $\left\{\sigma_{0}, v_{0}, A_{0} / P_{0},[\varepsilon], h_{t}\right\}$ :

$$
\begin{array}{cc} 
& (B A \vee M) \& B A \& L \&(L \vee B A) \&(M \vee B A) \rightarrow L \\
R^{\vee(5)}: & B A \&(M \vee B A) \&(L \vee B A) \&(B A \vee M \vee A A) \&(L \vee B A) \rightarrow B A
\end{array}
$$

Obviously, it would be advisable to evaluate the informational characteristics of all variables by their individual values, but this is beyond the scope of this study.

To numerically illustrate the operation of the designed FKB, a sample was used: initial voltage $\sigma_{0}=920,3579 \mathrm{MPa}$; corrosion rate $v_{0}=0,11567 \mathrm{~cm} /$ year; initial area and perimeter of an element $A_{0}=32,0856 \mathrm{~cm}^{2}$ and $P_{0}=27,60186 \mathrm{~cm}$; maximum permissible error values $[\varepsilon]=0,048$; integration step $h_{t}=1,2$ year.

For definiteness, we give the corresponding values of the term-sets of linguistic variables: initial voltage - "H"; corrosion rate - "H" or "BA"; the ratio of the area to the perimeter is " $\mathrm{H}$ " or "BA"; the maximum permissible error values are "L" or "BA"; integration step — "H" or "AA".

After working the fuzzy knowledge base, the degree of belonging of the input data is obtained: $\mu\left(\sigma_{0}\right)=0,663 ; \mu\left(v_{0}\right)=0,752 ; \mu\left(A_{0} / P_{0}\right)=0,976 ; \mu([\varepsilon])=0,9598 ; \mu\left(h_{t}\right)=0,989$.

The rules turned out to be active under the number one of the basic rules base and supplemented to it, therefore, the output variable, the forecasted value of the durability $t^{*}$ should be either average or above average ("M" or "AA"). The center of this cluster for the value of durability $t_{1 k l}=4,9972$ years.

Using the fuzzy logical conclusion of Mamdani and the method of heights, it is possible to obtain a defuzzified value of the forecast value $t^{*}$. As it is known, there are a sufficient number of defazzification methods. Without loss of generality of reasoning, the method of heights [21] was used in the work and the desired was obtained value $t_{d e f}=4,47$ years. It can be argued that the expert's confidence level of this value has a pessimistic forecast of 0,663 and an optimistic 0,989 .

It should be noted that in this case, to verify the results obtained, the reference value of the durability was calculated $t^{*}=4,6507$ years of the model structure, which was calculated with a sufficiently small integration step $h_{t}=0,00078$ years [21]. The reference solution can be considered asymptotically exact and obtained for comparing the numerical results. However, the calculation of 
standard solutions is quite expensive and this approach to solving optimal design tasks is unjustified or generally unsuitable.

\section{Conclusions}

The results of numerical experiments for the test sample demonstrate fairly close values of the forecasted CS durability. Moreover, the fuzzy knowledge base, as a rule, offers it slightly less than in the test sample, which is quite acceptable for the task being solved.

The multi-stage approach proposed in the work for working with multidimensional data arrays using fuzzy clustering allows to formalize the initial information. The resulting reference rule base serves as the basis for a numerically complete rule base. The results of numerical experiments make it possible to assert that a fuzzy clustering system allows to obtain a forecasted value of durability in modeling the behavior of corroding structures.

\section{References}

[1] Chuen-Chien Lee (1990) Fuzzy Logic in Control Systems: Fuzzy Logic Controller, Part I1. IEEE Transactions on systems, man, and cybernetics. 1990/3. - Vol. 20, № 2. - P. 404-418.

[2] Egorov A.V., Kuprijanova N.I. (2010) Osobennosti metodov klasterizaciju. [Features of clustering methods] Izvestija JuFU. Tehnicheskie naukiju Tematicheskij vypusk. S. 174-178. (in Russian).

[3] Harmider L.D., Taranenko I.V., Korotka L.I., Begma P.O. (2019) Methodological approach to labor potential assessment based on the use of fuzzy sets theory Naukovyi Visnyk Natsionalnoho Hirnychoho Universytetu. № 6 - 2019. 144-149 p. http://dx.doi.org/10.29202/nvngu/2019-6/21

[4] Korotkaya L. I. (2018) Algoritm polucheniya uchebnyih obraztsov dlya neyronnoy seti pri reshenii zadach dolgovechnosti korrodiruyuschih konstruktsiy [Algorithm for obtaining training samples for a neural network in solving problems of predicting the durability of design that are subject to corrosion] // Computer modeling: analysis, control, optimization. - № 1(3). - P. 8-25. (in Russian). http://dx.doi.org/10.32434/2521-6406-2018-3-1

[5] Korotka L. I, Zelentsov D. G. Method of solving optimal design problems based on flexible tolerance strategy International Journal of Mathematical Modelling and Numerical Optimisation, 2020 Vol.10 No.3 - pp. 255-269. (DOI: 10.1504/IJMMNO.2020.108613)

[6] Korotka L.I., Korotka Y. A. (2017) The use of elements of computational intelligence in problems of forecasting of corroding constructions durability. Mathematical and computer modelling. Series: Technical sciences. - Issue 16. - P. 64-71.

[7] Kosko B. (1994) Fuzzy Systems as Universal Approximators. IEEE Trans. on Computers. Vol. 43. №11. P.1329-1333.

[8] Lee J, Kim T. A messy genetic algorithm and its application to an approximate optimization of an occupant safety system. Journal of Automobile Engineering. 2009;757-758.

[9] Monyei CG, Aiyelari T, Oluwatunde S. Neural Network Modeling of Electronic Waste Deposits in Nigeria: Subtle Prod for quick Intervention' in proceedings of the iSTEAMS Research. Nexus Multidisciplinary Conference. 2013; 1(4):181-188.

[10] Nicholas Ali, Kumaran Behdinan, Zouheir Fawaz, "Applicability and Viability of a GA based Finite Element Analysis Architecture for Structural Design Optimization," Computers and Structures, 81, 2259-2271, 2003.

[11] Ovchinnikov I.G. Matematicheskie modeli korrozionnogo iznosa nezaschischennyih metallicheskih konstruktsiy [Mathematical models of corrosive wear of unprotected metal constructions] / I.G. Ovchinnikov, I.I. Ovchinnikov // Promyishlennyie pokryitiya. 2014. Vyip. №№9-10. S. 76-79. (in Russian).

[12] Piegat Andrzej (2001) Fuzzy Modeling and Control: with 96 tables / Andrzej Piegat. Heidelberg: New York: Physica-Verl. 728 p.

[13] Pochtman Yuriy Optimal design of pressure vessels including the effect of environment / Pochtman Yuriy M., Fridman Mark M. // Computer Assisted Mechanics and Engineering Sciences 1995.

[14] Shtovba S.D., Galuschak A.V. (2016) Kriteriyi navchannya nechitkogo klasifikatora na osnovi vidstani mizh golovnimi konkurentami [Fuzzy classifier learning based on distance between the 
main competitors]. Radio Electronics, Computer Science, Control. - № 2. - P. 70-76. (in Ukrainian)

[15] Shtovba S. Ensuring accuracy and transparency of Mamdani fuzzy model in learning by experimental data / S. Shtovba // Journal of Automation and Information Sciences. - 2007. Vol. 39, № 8. - P. 39-52.

[16] Shtovba S. Analyzing the criteria for fuzzy classifier learning / S. Shtovba, O. Pankevich, A. Nagorna // Automatic Control andComputer Sciences. - 2015. - Vol. 49, № 3. - P. 123-132

[17] Solodka N.A., Shapovalov D.D. (2019) Analiz i obrabotka dannyh kompanii kak sposob povyshenija ee pribyl'nosti [Analysis and processing of company data as a method of profitability improving]. Elektronnij naukovo-praktichnij zhurnal «Shidna Cvropa: ekonomika, biznes ta upravlinnja» - № 6 (23) - S. 756-760 (in Russian).

[18] Us S.A., Korjashkina L.S. Modeli ta metody pryjnjattja rishen' (druge vydannja) [Models and methods of decision making] // Dnipropetrovs'k, NGU, 2018, 270 s.

[19] Zadeh Lotfi A. (1975) The concept of a linguistic variable and its application to approximate reasoning. / Lotfi A. Zadeh // Part 1 Information Sciences. 8(3), P. 199-249.

[20] Zelentsov, D., Denysiuk, O. (2019) Neural Network Algorithm for Accuracy Control in Modelling of Structures with Changing Characteristics. In: Hu Z., Petoukhov S., Dychka I., He M. (eds) Advances in Computer Science for Engineering and Education. ICCSEEA 2018. Advances in Intelligent Systems and Computing, vol 754. Springer.

[21] Zelentsov D. G., Korotkaya L. I. (2018) Tehnologii vyichislitelnogo intellekta v zadachah modelirovaniya dinamicheskih sistem: monografiya. [Technologies of computational intelligence in tasks of dynamic systems modeling: monograph] / D. G. Zelentsov, L. I. Korotkaya // - Dnepr: Balans-Klub. - 178 p. (in Russian).

(http://dx.doi.org/10.32434/mono-1-ZDG-KLI)

\section{НЕЧІТКА КЛАСТЕРИЗАЦІЯ ДЛЯ ФОРМАЛІЗАЦІЇ НЕПОВНОЇ ІНФОРМАЦІЇ В ЗАДАЧАХ ПРОГНОЗУВАННЯ ДОВГОВІЧНОСТІ КОРОДУЮЧИХ КОНСТРУКЦІЙ \\ Коротка Л.І.}

\section{Реферат}

При вирішенні задач прогнозування довговічності кородуючих конструкцій та їх оптимального проектування (в роботі пряма та обернена задача) виникає необхідність обробки багатовимірних масивів даних для підвищення ефективності обчислювальних алгоритмів. Запропоновано формалізувати наявну інформацію, яка представлена у вигляді багатовимірних масивів дискретних величин, використовуючи багатоступеневий підхід. Він включає такі основні кроки: нечітку кластеризацію вхідних даних (робота fcm-алгоритму); формалізацію даних по кожному кластеру у вигляді нечіткої бази знань: перевизначення опорної бази правил; безпосереднє застосування нечіткого виведення (наприклад, у роботі алгоритм Мамдані) та дефазифікація методом висот.

Пропонується записати правила для нечіткої бази знань та набору термів лінгвістичних змінних, використовуючи інформацію, яка отримана після виконання процесу кластеризації. В якості носія множини термів розглядаються заздалегідь визначені межі кожного нечіткого кластера, а центр відповідного кластера розглядається як його ядро. Для формального представлення функцій належності використовується $\alpha$-рівневий принцип узагальнення. Розглянуто важливі властивості правил отриманої бази знань, які пропонується використати для визначення бази правил. Запропоновано нечітку модель представлення знань при розв’язанні задач указаного класу. 
Використовуючи нечітке логічне виведення Мамдані та метод висот, можна отримати прогнозоване значення довговічності кородуючих конструкцій. В якості альтернативи нейронним мережам при вирішення задач апроксимації пропонується застосувати багатоступеневий підхід, заснований на нечіткій кластеризації та теорії нечітких множин.

Запропонований підхід дозволяє формалізувати наявну нечітку інформацію для задач такого класу. Більш точне коригування отриманої бази знань має незалежне значення і вимагає окремого розгляду.

Результати чисельних експериментів дають змогу стверджувати, що запропонована система нечіткої кластеризації дозволяє прогнозувати довговічність конструкцій, які функціонують в агресивних середовищах, та, як наслідок, зменшити обчислювальні витрати.

\section{Література}

1. [1] Chuen-Chien Lee Fuzzy Logic in Control Systems: Fuzzy Logic Controller, Part II. IEEE Transactions on systems, man, and cybernetics. 1990/3. Vol. 20, № 2. P. 404-418.

2. [2] Егоров А .В., Куприянова Н. И. Особенности методов кластеризации. Известия ЮФУ. Технические науки. 2010.Тематический выпуск. С. 174-178.

3. [3] Harmider L. D., Taranenko I. V., Korotka L. I., Begma P. O. Methodological approach to labor potential assessment based on the use of fuzzy sets theory. Naukovyi Visnyk Natsionalnoho Hirnychoho Universytetu. 2019. № 6. P. 144-149. (DOI: http://dx.doi.org/10.29202/nvngu/2019$6 / 21)$

4. [4] Короткая Л.И. Алгоритм получения учебных образцов для нейронной сети при решении задач долговечности корродирующих конструкций. Компьютерное моделирование: анализ, управление, оптимизащия. 2018. № 1(3). С. 8-25. (DOI: http://dx.doi.org/10.32434/2521-6406-2018-3-1)

5. [5] Korotka L. I, Zelentsov D. G. Method of solving optimal design problems based on flexible tolerance strategy. International Journal of Mathematical Modelling and Numerical Optimisation. 2020. Vol.10. No.3 P. 255-269.

(DOI: http://dx.doi.org/10.1504/IJMMNO.2020.108613)

6. [6] Korotka L. I., Korotka Y. A. The use of elements of computational intelligence in problems of forecasting of corroding constructions durability. Mathematical and computer modelling. Series: Technical sciences. 2017. Issue 16. P. 64-71.

7. [7] Kosko B. Fuzzy Systems as Universal Approximators. IEEE Trans. on Computers. 1994. Vol. 43. №11. P. 1329-1333.

8. [8] Lee J, Kim T. A messy genetic algorithm and its application to an approximate optimization of an occupant safety system. Journal of Automobile Engineering. 2009. P. 757-758.

9. [9] Monyei CG., Aiyelari T., Oluwatunde S. Neural Network Modeling of Electronic Waste Deposits in Nigeria: Subtle Prod for quick Intervention' in proceedings of the iSTEAMS Research. Nexus Multidisciplinary Conference. 2013. № 1(4). P. 181-188.

10. [10] Nicholas Ali, Kumaran Behdinan, Zouheir Fawaz Applicability and Viability of a GA based Finite Element Analysis Architecture for Structural Design Optimization. Computers and Structures. 2003. № 81, Р. 2259-2271.

11. [11] Овчинников И.Г., Овчинников И.И. Математические модели коррозионного износа незащищенных металлических конструкций. Промышленные покрытия. 2014. Вып. №№910. C. 76-79.

12. [12] Piegat Andrzej Fuzzy Modeling and Control. Heidelberg: New York: Physica-Verl. 2001. $728 \mathrm{p}$.

13. [13] Pochtman Yuriy, Fridman Mark M. Optimal design of pressure vessels including the effect of environment Computer Assisted Mechanics and Engineering Sciences. 1995.

14. [14] Штовба С.Д., Галущак А.В. Критерії навчання нечіткого класифікатора на основі відстані між головними конкурентами. Радіоелектроніка, інформатика, управління. 2016. № 2. C. 70-76. 
15. [15] Shtovba S. Ensuring accuracy and transparency of Mamdani fuzzy model in learning by experimental data. Journal of Automation and Information Sciences. 2007. Vol. 39, № 8. P. 39-52.

16. [16] Shtovba S., Pankevich O., Nagorna A. Analyzing the criteria for fuzzy classifier learning. Automatic Control andComputer Sciences. 2015. Vol. 49, № 3. P. 123-132.

17. [17] Солодкая Н. А., Шаповалов Д. Д. Анализ и обработка данных компании как способ повышения ее прибыльности. Електронний науково-практичний журнал "Східна Свропа: економіка, бізнес та управління». 2019. № 6 (23). С. 756-760

18. [18] Ус С. А., Коряшкіна Л. С. Моделі та методи прийняття рішень (друге видання). Дніпропетровськ: НГУ, 2018. 270 с.

19. [19] Zadeh Lotfi A. The concept of a linguistic variable and its application to approximate reasoning. Part 1 Information Sciences. 1975. 8(3). P. 199-249.

20. [20] Zelentsov D., Denysiuk O. Neural Network Algorithm for Accuracy Control in Modelling of Structures with Changing Characteristics. Advances in Computer Science for Engineering and Education. ICCSEEA 2018. Advances in Intelligent Systems and Computing: In: Hu Z., Petoukhov S., Dychka I., He M. (eds). 2019. vol. 754. P. 507-516. (Springer)

21. [21] Зеленцов Д. Г., Короткая Л. И. Технологии вычислительного интеллекта в задачах моделирования динамических систем. Днепр: Баланс-клуб, 2018. 178. (DOI: http://dx.doi.org/10.32434/mono-1-ZDG-KLI) 